Prepared in cooperation with the Bureau of Reclamation and the USGS Groundwater Resources Program

\title{
Documentation of Input Datasets for the Soil-Water Balance Groundwater Recharge Model of the Upper Colorado River
} Basin

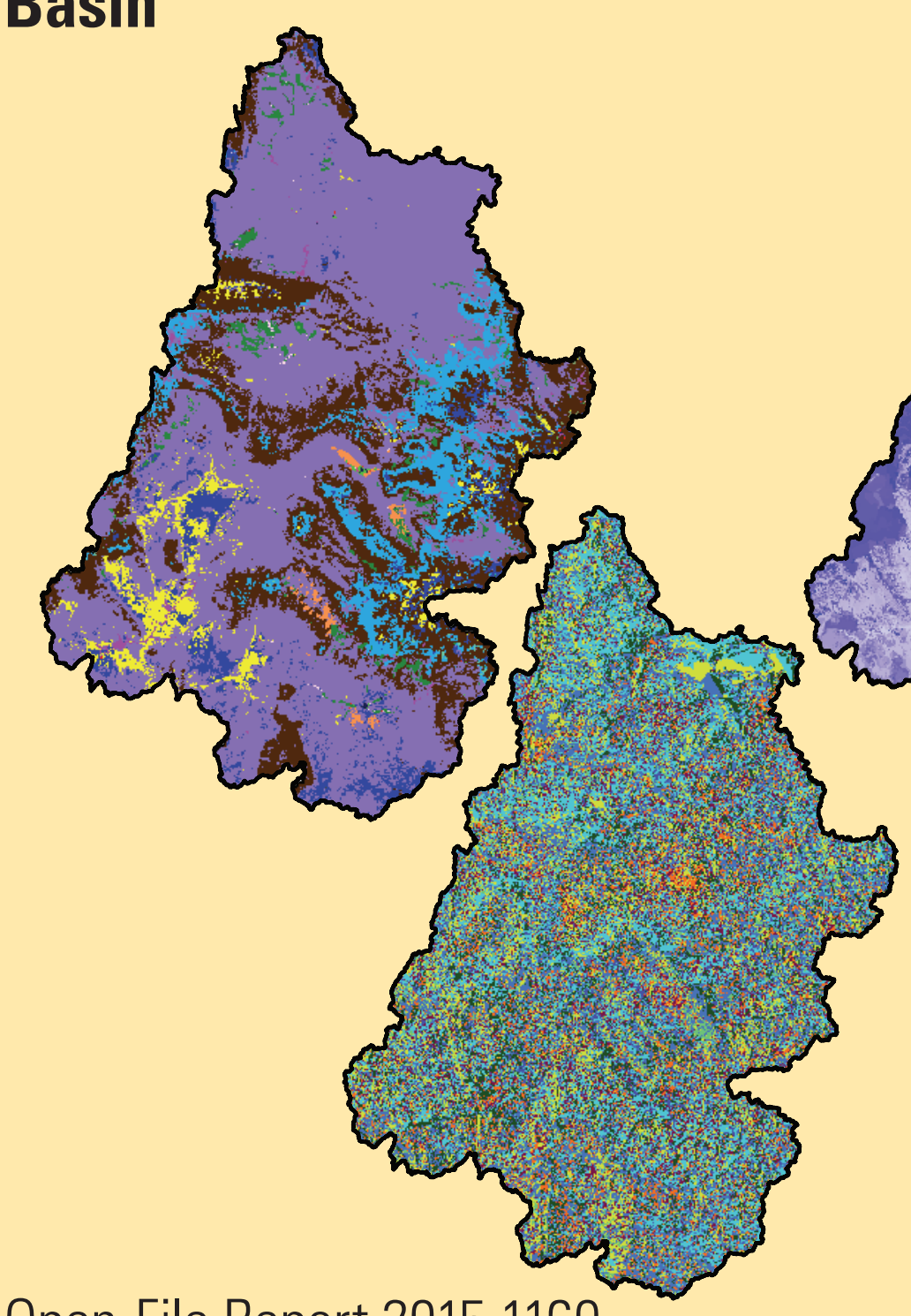

Open-File Report 2015-1160

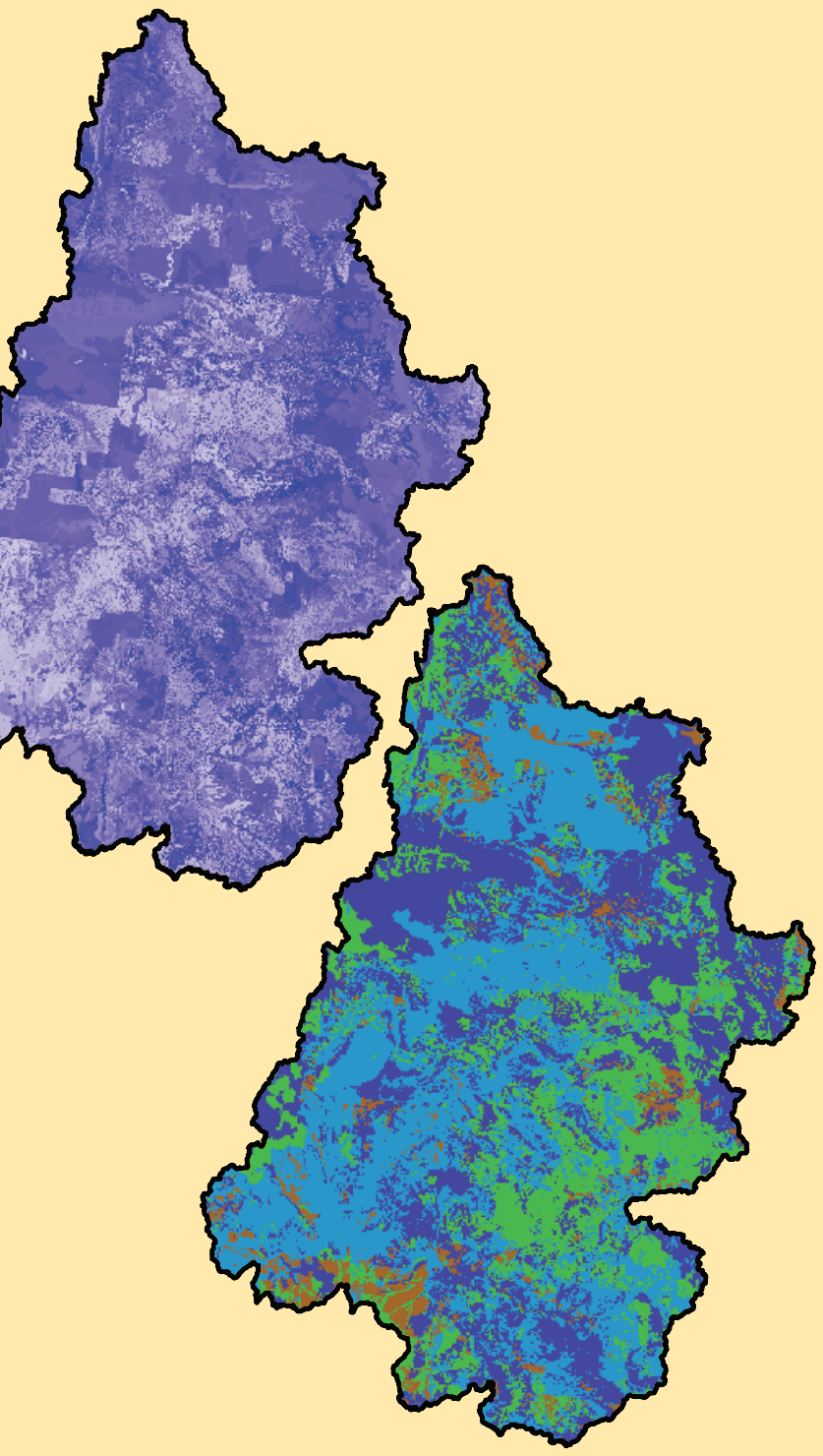


Cover. Maps of the Upper Colorado River Basin showing (clockwise from top left) land-cover classifications, available water capacity, hydrologic soil group, and overland flow direction. 


\section{Documentation of Input Datasets for the Soil-Water Balance Groundwater Recharge Model of the Upper Colorado River Basin}

By Fred D Tillman

Prepared in cooperation with the Bureau of Reclamation and the USGS Groundwater Resources Program

Open-File Report 2015-1160 


\title{
U.S. Department of the Interior SALLY JEWELL, Secretary
}

\section{U.S. Geological Survey Suzette M. Kimball, Acting Director}

\author{
U.S. Geological Survey, Reston, Virginia: 2015
}

For more information on the USGS - the Federal source for science about the Earth, its natural and living resources, natural hazards, and the environment-visit http://www.usgs.gov or call 1-888-ASK-USGS (1-888-275-8747).

For an overview of USGS information products, including maps, imagery, and publications, visit http://www.usgs.gov/pubprod/.

Any use of trade, firm, or product names is for descriptive purposes only and does not imply endorsement by the U.S. Government.

Although this information product, for the most part, is in the public domain, it also may contain copyrighted materials as noted in the text. Permission to reproduce copyrighted items must be secured from the copyright owner.

Suggested citation:

Tillman, F.D, 2015, Documentation of input datasets for the soil-water balance groundwater recharge model of the Upper Colorado River Basin: U.S. Geological Survey Open-File Report 2015-1160, 17 p., http://dx.doi.org/10.3133/ ofr20151160.

ISSN 2331-1258 (online) 


\section{Acknowledgments}

Development of the Soil-Water Balance groundwater recharge model for the Upper Colorado River Basin was supported by the Bureau of Reclamation and the USGS Groundwater Resources Program. Stephen Westenbroek, USGS, provided technical assistance with Soil-Water Balance model simulations.

\section{Contents}

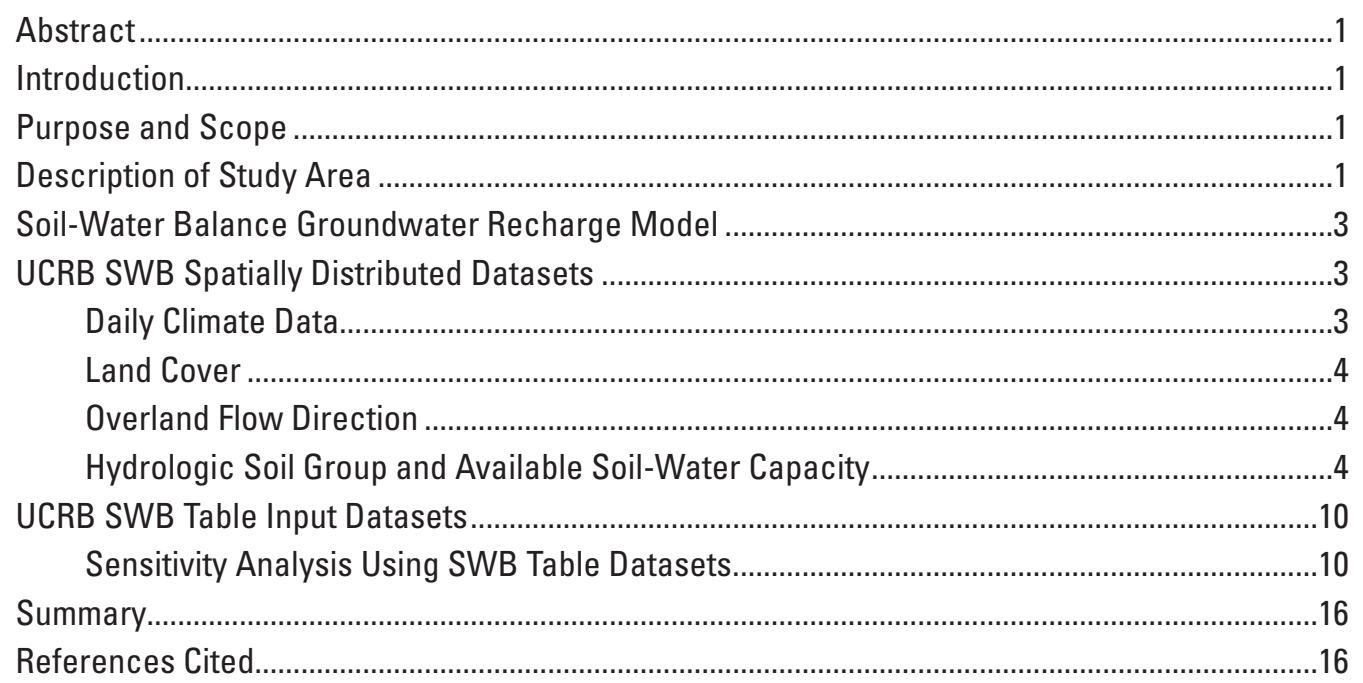

\section{Figures}

1. Maps of the Upper Colorado River Basin showing its location, major streams, average annual precipitation, and major land-cover classifications.....

2. Graphs showing monthly precipitation time series data from Daymet and Maurer and others (2002), datasets for Upper Colorado River Basin including all data, and overlapping time period of 1980-99

3. Graphs showing average monthly minimum temperature time series data from Daymet and Maurer and others (2002), datasets for Upper Colorado River Basin including all data, and overlapping time period of 1980-99

4. Graphs showing average monthly maximum temperature time series data from Daymet and Maurer and others (2002), datasets for Upper Colorado River Basin including all data, and overlapping time period of 1980-99

5. Maps showing National Land Cover Database coverage of the Upper Colorado River Basin study area including the original resolution and resampled resolutions corresponding to Daymet climate dataset and Maurer and other (2002) climate dataset....................................... 8

6. Maps showing overland flow direction from each cell in the Upper Colorado River Basin study area from digital elevation models in original resolution, and resampled resolutions corresponding to Daymet climate dataset and Maurer and others (2002) climate dataset. 


\section{Figures-Continued}

7. Map showing coverage of the Upper Colorado River Basin study area by gSSURGO and STATSGO2 soils-information datasets.

8. Maps showing percentage of coverage of available water capacity for the Upper Colorado River Basin study area including data in original gSSURGO dataset resolution, and resampled resolutions corresponding to Daymet climate dataset and Maurer and others (2002) climate dataset.

9. Maps showing Hydrologic Soil Group for the Upper Colorado River Basin study area including data in original gSSURGO dataset resolution, and resampled resolutions corresponding to Daymet climate dataset and Maurer and others (2002) climate dataset.

\section{Tables}

1. Soil-water balance model lookup table values and citations for runoff curve numbers.

2. Soil-water balance model lookup table values and citations for vegetation root-zone depths.

3. Sensitivity of Upper Colorado River Basin soil-water balance model simulated recharge results for different lookup-table values.

\section{Conversion Factors}

Inch/Pound to International System of Units

\begin{tabular}{|c|c|c|}
\hline Multiply & By & To obtain \\
\hline \multicolumn{3}{|c|}{ Length } \\
\hline inch (in.) & 2.54 & centimeter $(\mathrm{cm})$ \\
\hline foot (ft) & 0.3048 & meter $(\mathrm{m})$ \\
\hline mile (mi) & 1.609 & kilometer $(\mathrm{km})$ \\
\hline \multicolumn{3}{|c|}{ Area } \\
\hline acre & 4,047 & square meter $\left(\mathrm{m}^{2}\right)$ \\
\hline square mile $\left(\mathrm{mi}^{2}\right)$ & 259.0 & hectare (ha) \\
\hline square mile $\left(\mathrm{mi}^{2}\right)$ & 2.590 & square kilometer $\left(\mathrm{km}^{2}\right)$ \\
\hline \multicolumn{3}{|c|}{ Volume } \\
\hline acre-foot (acre-ft) & 1,233 & cubic meter $\left(\mathrm{m}^{3}\right)$ \\
\hline
\end{tabular}

International System of Units to Inch/Pound

\begin{tabular}{llll}
\hline & Multiply & By & To obtain \\
\hline & Length & \\
\hline meter $(\mathrm{m})$ & 3.281 & foot $(\mathrm{ft})$ & \\
\hline
\end{tabular}

Temperature in degrees Celsius $\left({ }^{\circ} \mathrm{C}\right)$ may be converted to degrees

Fahrenheit $\left({ }^{\circ} \mathrm{F}\right)$ as ${ }^{\circ} \mathrm{F}=\left(1.8 \times{ }^{\circ} \mathrm{C}\right)+32$.

Temperature in degrees Fahrenheit $\left({ }^{\circ} \mathrm{F}\right)$ may be converted to degrees

Celsius $\left({ }^{\circ} \mathrm{C}\right)$ as ${ }^{\circ} \mathrm{C}=\left({ }^{\circ} \mathrm{F}-32\right) / 1.8$. 


\section{Datum}

Vertical coordinate information is referenced to the North American Vertical Datum of 1988 (NAVD88).

Horizontal coordinate information is referenced to the North American Datum of 1983 (NAD83).

Altitude, as used in this report, refers to distance above the vertical datum.

\section{Abbreviations}

$\begin{array}{ll}\text { APWL } & \text { Accumulated Potential Water Loss } \\ \text { AWC } & \text { Available water capacity } \\ \text { CMIP } & \text { Coupled Model Intercomparison Project } \\ \text { DCHP } & \text { Downscaled Climate and Hydrology Projections } \\ \text { DEM } & \text { Digital elevation model } \\ \text { HSG } & \text { Hydrologic soil group } \\ \text { HUC } & \text { Hydrologic unit code } \\ \text { NASA } & \text { National Aeronautics and Space Administration } \\ \text { NLCD } & \text { National Land Cover Database } \\ \text { NRCS } & \text { Natural Resources Conservation Service } \\ \text { PRISM } & \text { Parameter-elevation Relationships on Independent Slopes Model } \\ \text { SWB } & \text { Soil-Water Balance } \\ \text { USDA } & \text { U.S. Department of Agriculture } \\ \text { USGS } & \text { U.S. Geological Survey } \\ \text { UCRB } & \text { Upper Colorado River Basin } \\ \text { VBA } & \text { Visual basic for applications }\end{array}$





\title{
Documentation of Input Datasets for the Soil-Water Balance Groundwater Recharge Model of the Upper Colorado River Basin
}

\author{
By Fred D Tillman
}

\begin{abstract}
The Colorado River and its tributaries supply water to more than 35 million people in the United States and 3 million people in Mexico, irrigating more than 4.5 million acres of farmland, and generating about 12 billion kilowatt hours of hydroelectric power annually. The Upper Colorado River Basin, encompassing more than 110,000 square miles $\left(\mathrm{mi}^{2}\right)$, contains the headwaters of the Colorado River (also known as the River) and is an important source of snowmelt runoff to the River. Groundwater discharge also is an important source of water in the River and its tributaries, with estimates ranging from 21 to 58 percent of streamflow in the upper basin. Planning for the sustainable management of the Colorado River in future climates requires an understanding of the Upper Colorado River Basin groundwater system. This report documents input datasets for a Soil-Water Balance groundwater recharge model that was developed for the Upper Colorado River Basin.
\end{abstract}

\section{Introduction}

More than 35 million people in the United States and 3 million people in Mexico depend on the Colorado River to supply their domestic and industrial water needs (Bureau of Reclamation, 2011; Colorado River Basin Salinity Control Forum, 2013). The Colorado River (as known as the River) also supplies irrigation water for more than 4.5 million acres of land in the United States and Mexico, and generates about 12 billion kilowatt hours annually of hydroelectric power along the River and its tributaries (Colorado River Basin Salinity Control Forum, 2011). Miller and others (2014) estimated that annual discharge of groundwater to rivers and streams (base flow) in the Upper Colorado River Basin (UCRB) can range from 21 to 58 percent of streamflow, with higher percentages during low-flow conditions. Recently, a study by Castle and others (2014) using remotely sensed gravity observations from the NASA Gravity Recovery and Climate Experiment (GRACE) mission found that UCRB groundwater was depleted by more than 17 million acre-feet (ft) from December 2004 to November 2013. Understanding groundwater-budget components, including groundwater recharge, is important to sustainably manage both groundwater and surface-water supplies in the Colorado River Basin.

\section{Purpose and Scope}

This report documents and discusses the origin and manipulation of input datasets for the Soil-Water Balance groundwater recharge model of the UCRB. This documentation will serve as a reference for future publications on the results from groundwater-recharge simulations using this model. Soil-Water Balance simulation results are not discussed in this report, except briefly in the investigation of the sensitivity of simulated recharge results to table input values.

\section{Description of Study Area}

The Colorado River Basin drains parts of Wyoming, Utah, Colorado, New Mexico, Arizona, Nevada, California, and Mexico, and is divided into upper and lower basins at the compact point of Lee Ferry, Arizona, a location 1 mile (mi) downstream of the mouth of the Paria River (fig. 1A, 1B; Anderson, 2004). The UCRB is defined for this study as the 113,406-square-mile $\left(\mathrm{mi}^{2}\right)$ drainage area (hydrologic unit code 14 [HUC14]) upstream of U.S. Geological Survey (USGS) streamflow-gaging station 09380000, Colorado River at Lees Ferry, Arizona (fig. 1B). Major tributaries to the Colorado River in the Upper Basin include the Dolores, Green, Gunnison, San Juan, White, and Yampa Rivers (fig. 1B). Average annual precipitation ranges from less than 10 inches (in.) in low-elevation areas to more than 39 in. in high elevation areas in the Southern Rocky Mountains (fig. $1 C$, PRISM Climate Group, 2012). The UCRB varies in elevation from about 3,100 ft near the Lees Ferry streamgage to more than $14,000 \mathrm{ft}$ in peaks in the Southern Rocky Mountains in the eastern part of the UCRB (Liebermann and others, 1989). UCRB land cover is predominately shrub/scrub and evergreen forest (Fry and others, 2011), with few high-density population centers (fig. 1D). 

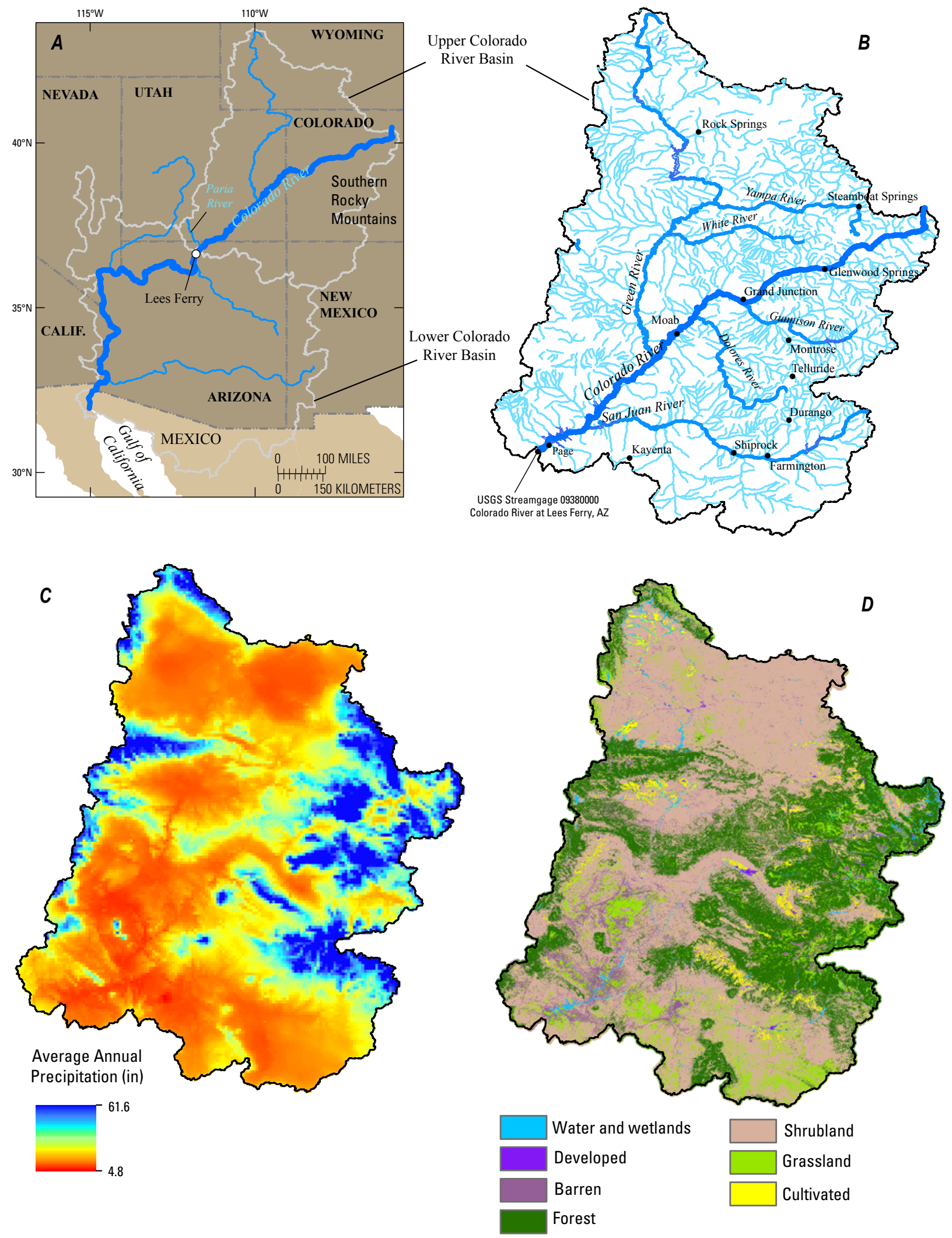

Figure 1. Maps of the Upper Colorado River Basin showing $(A)$ its location, $(B)$ major streams, $(C)$ average annual precipitation (PRISM Climate Group, 2012), and (D) major land-cover classifications (Fry and others, 2011). 
Aquifers in the UCRB are composed of permeable, moderately to well-consolidated sedimentary rocks ranging in age from Permian to Tertiary (Robson and Banta, 1995). At least three groups of regional, productive water-yielding geologic units have been identified in the UCRB including Tertiary aquifers of limited extent in the northern and southeastern parts of the basin, Mesozoic aquifers throughout most of the study area, and deeper Paleozoic aquifers also throughout much of the study area (Robson and Banta, 1995; Geldon 2003a,b; Freethey and Cordy, 1991). The Chinle-Moenkopi confining unit limits communication of water between Mesozoic and Paleozoic aquifers throughout much of the UCRB (Geldon 2003a,b; Freethey and Cordy, 1991).

\section{Soil-Water Balance Groundwater Recharge Model}

The Soil-Water-Balance (SWB) computer code (Westenbroek and others, 2010) estimates groundwater recharge by calculating water-balance components at daily time steps for each model cell using a modified version of the ThornthwaiteMather soil-water-balance approach:

$$
\begin{aligned}
& \text { sources of water sinks of water } \\
& \text { (rainfall }+ \text { snowmelt }+ \text { inflow })-(\text { interception }+ \text { outflow }+ \text { ET }) \\
& -\Delta \text { soil moisture }=\text { RECHARGE }
\end{aligned}
$$

In the SWB model, snow accumulates or melts on a daily basis based on air temperature. Inflow to a cell is surface flow from adjacent cells, calculated using the Natural Resources Conservation Service curve number rainfall-runoff method (U.S. Department of Agriculture, 2004). The direction of runoff from cell to cell is determined by using a flow-direction grid derived from a digital elevation model (DEM). Interception is a user-specified amount of precipitation that is trapped and used by vegetation. Outflow from a cell is calculated using the same method as inflow to the cell. There are several methods available for estimating evapotranspiration (ET) in the SWB model. For the UCRB simulations, the Hargreaves-Samani (1985) method is used as it produces spatially variable estimates of potential ET (PET) from spatially varying minimum and maximum air temperature data for each daily time step:

$\mathrm{PET}=0.0135 \times \mathrm{RS} \times(\mathrm{T}+17.8)$ with $\mathrm{RS}=\mathrm{K}_{\mathrm{RS}} \times \mathrm{RA} \times \mathrm{TD}^{0.5}$

where PET is potential ET, RS is incoming solar radiation, $\mathrm{T}$ is mean air temperature in ${ }^{\circ} \mathrm{C}, \mathrm{K}_{\mathrm{RS}}$ is a calibration coefficient, $\mathrm{RA}$ is extraterrestrial radiation, and TD is the measured air temperature range (Hargreaves and Samani, 1985). Extraterrestrial radiation is estimated as a function of the day of year and latitude following the method of Allen and others (2006). The computation of soil moisture in equation 1 requires several intermediary values. First, PET is subtracted from precipitation (P) for all grid cells. If $\mathrm{P}-\mathrm{PET}$ is negative (that is, if $\mathrm{P}<\mathrm{PET}$ ), then there is a potential deficiency of water. Accumulated Potential Water Loss (APWL) is computed as the running sum of daily $\mathrm{P}$ - PET values during times when $\mathrm{P}<\mathrm{PET}$. Soil moisture is estimated using the current AWPL value in the Thornthwaite-Mather relation that describes the nonlinear relation between soil moisture and APWL. Actual ET (AET) is then equal to only the amount of water that can be extracted from the soil. If $\mathrm{P}-\mathrm{PET}$ is positive (that is, if $\mathrm{P}>\mathrm{PET}$ ), a potential surplus of water exists and AET is equal to PET. Soil moisture is calculated by adding $\mathrm{P}$ - PET directly to the previous day's soil-moisture value. If the new soil moisture value is less than the maximum water-holding capacity of the soil (calculated as the product of the available soil water capacity and the rootzone depth), then the Thornthwaite-Mather relation is used to back-calculate a reduced APWL. If the new soil moisture value is greater than the maximum water-holding capacity of the soil, then soil moisture is capped at the maximum water-holding capacity, excess soil-moisture becomes recharge, and AWPL is set to zero. See Westenbroek and others (2010) for detailed explanations of SWB processes.

\section{UCRB SWB Spatially Distributed Datasets}

Five spatially distributed (gridded) datasets are required for SWB recharge simulations. All gridded datasets must be in ASCII format (except climate data which also may be in NetCDF format), cover an area that is rectangular in shape with all cells having valid values (that is, "no data" values are not allowed), have the same geographic projection, the same cell size and extent, and must overlap exactly. Required gridded datasets include daily climate data (precipitation, maximum and minimum air temperature), land cover, overland flow direction, hydrologic soil group, and available soil-water capacity. The source and manipulation of these spatially distributed datasets for UCRB SWB groundwater recharge simulations are described in this section.

\section{Daily Climate Data}

Daily climate data of precipitation (in inches) and maximum and minimum temperature (in degrees Fahrenheit) for all grid cells covering the model area are required for SWB recharge simulations using the Hargreaves-Samani (1985) method for estimating ET (equation 2). Two climate datasets of different resolutions are used in this report as spatial templates for rescaling other gridded datasets described in this section. Comparing input datasets scaled to different resolutions can provide insight on how much information may be lost as datasets are interpolated from their original resolution to coarser grids. The non-climate SWB datasets described in this report, however, may be re-gridded to work with any scale of available climate data. The first climate dataset is produced by Oak Ridge National Laboratory and is known as Daymet data (http://daymet.ornl.gov/). Daymet climate data are produced by interpolating spatially referenced ground 
observations and are available in daily time steps in grid cell sizes of $1,000 \mathrm{~m}$ by $1,000 \mathrm{~m}$ for all of North America. Daymet data were downloaded in seventeen 2 by 2-degree NetCDF grids to cover the UCRB study area, mosaicked together using the opensource FWTools tool kit (http://fwtools.maptools.org), and clipped to the UCRB study area using the ArcGIS "extract by mask" tool. Daymet climate data were available from 1980 onward. The second climate dataset used for SWB recharge simulations was obtained from the Downscaled Climate and Hydrology Projections (DCHP) website at http://gdo-dcp.ucllnl.org/downscaled_cmip projections/. The DCHP website is a multiagency collaborative effort begun in 2007 and supported by the Bureau of Reclamation (Reclamation), Climate Analytics Group, Climate Central, Lawrence Livermore National Laboratory, Santa Clara University, Scripps Institution of Oceanography, U.S. Army Corps of Engineers, and the USGS. The DCHP website serves daily and monthly Coupled Model Intercomparison Project (CMIP) phase 3 and CMIP5 climate projection data, as well as observed climate data. Resolution of the DCHP data is $1 / 8^{\text {th }}$ degree (140 to 157 square kilometers $\left(\mathrm{km}^{2}\right)$ in the UCRB) and it is available for the North American Land-Data Assimilation System domain (http://ldas.gsfc.nasa.gov/). DCHP daily climate data are served in NetCDF formatted grids in units of millimeters $(\mathrm{mm})$ for precipitation and degrees Celsius for temperature. Observed (historical) climate data of Maurer and others (2002) were downloaded from the DCHP website to cover the UCRB study area and were used in SWB without manipulation. Maurer and others (2002) climate data were available from 1950 to 1999.

Total monthly precipitation volume from the Maurer and others (2002) dataset is about 10 percent larger than the Daymet dataset for the 1980-99 overlapping period of record (fig. 2), probably owing to the Maurer and others (2002) dataset covering about an 8 percent larger area $\left(113,838 \mathrm{mi}^{2}\right)$ than the Daymet dataset $\left(104,982 \mathrm{mi}^{2}\right)$. Daymet average minimum monthly temperatures for the UCRB appear to be somewhat higher than Maurer and others (2002) values, particularly during colder winter months (fig. 3). Average maximum monthly temperatures appear to be similar for both datasets (fig. 4).

\section{Land Cover}

The 2011 National Land Cover Database (NLCD; Homer and others, 2015) was used to characterize land cover in the UCRB study area. The NLCD is produced by the Multi-Resolution Land Characteristics consortium (http://www.mrlc.gov/about.php), and describes land cover across the United States using a 16-class classification scheme at a spatial resolution of 30 meters (m). The 2011 NLCD dataset for the conterminous United States was downloaded from http://www.mrlc.gov/nlcd11_data.php as an ArcGIS IMG raster in Albers Conical Equal Area (NAD83) spatial projection (fig. $5 A$ ). The national dataset was clipped to the UCRB boundary using the ArcGIS tool "extract by mask." To resample the NLCD dataset to obtain the same cell size, cell alignment, and geographic projection as the two climate datasets described above, the "project raster" tool was used, using the majority resampling technique, and the corresponding climate dataset raster to define the output cell size and "snap" raster (fig. $5 B$ and $C$ ). Systematic coarsening of the NLCD resolution from the original $30 \mathrm{~m}$ dataset to $1,000 \mathrm{~m}$ and $1 / 8^{\text {th }}$ degree grids results in some information loss. For example, small areas of woody and emergent wetlands appear in both the original and $1,000 \mathrm{~m}$ grids, but no wetlands appear in the $1 / 8^{\text {th }}$ degree grid (fig. 5 ). The percentage of coverage of most major classifications, however, appears to be relatively similar between different grid resolutions.

\section{Overland Flow Direction}

An overland flow direction grid is used by the SWB model to route runoff from cell to cell. SWB uses the D8 flow-routing convention (O'Callaghan and Mark, 1984) in which the unique flow direction from a cell is assigned a value based on the steepest slope between the cell and its eight surrounding neighbors (fig. 6). To generate the D8 flow-direction grids, one arc-second (roughly $30 \mathrm{~m}$ ) DEM grids were downloaded from the USGS National Map (http://viewer.nationalmap.gov/viewer/) to cover the UCRB study area. Individual DEM grids were mosaicked together using the ArcGIS "mosaic to new raster" tool. Terrain processing tools developed by the U.S. Army Corps of Engineers (http://www. hec.usace.army.mil/software/hec-geohms/) were used to fill sinks in the original DEM, and the ArcGIS "flow direction" tool was used to create the D8 flow-direction grid. The flow-direction grid was clipped to the UCRB boundary using the ArcGIS "extract by mask" tool (fig. 6A). To resample the flow-direction grid to obtain the same cell size, cell alignment, and geographic projection as the two climate datasets described above, the "project raster" tool was used, using the majority resampling technique, and the corresponding climate dataset raster to define the output cell size and "snap" raster (fig. $6 B$ and $C$ ). Comparisons between flowdirection grids of different scales are not meaningful.

\section{Hydrologic Soil Group and Available Soil-Water Capacity}

Two gridded soil-related properties, hydrologic soil group (HSG) and available water capacity (AWC), are used in SWB recharge simulations. HSG and AWC information has been compiled for the United States by the U.S. Department of Agriculture (USDA) Natural Resources Conservation Service (NRCS). As described by the NRCS, the HSG for an area is determined by the least water-transmitting layer in the soil column. NRCS classifies four HSGs from Group A (high infiltration capacity and low overland flow potential) to Group D (low infiltration capacity and high overland flow potential; U.S. Department of Agriculture, 2009). In SWB simulations, a lookup table incorporates HSG and land-cover information for each grid cell to define unique runoff curve numbers, vegetation rooting depths, interception values, and maximum daily recharge values (see next section). AWC is the amount of water that a soil can hold, and is between a soil's field capacity and the wilting point (U.S. Department of Agriculture, 1998). In SWB simulations, 

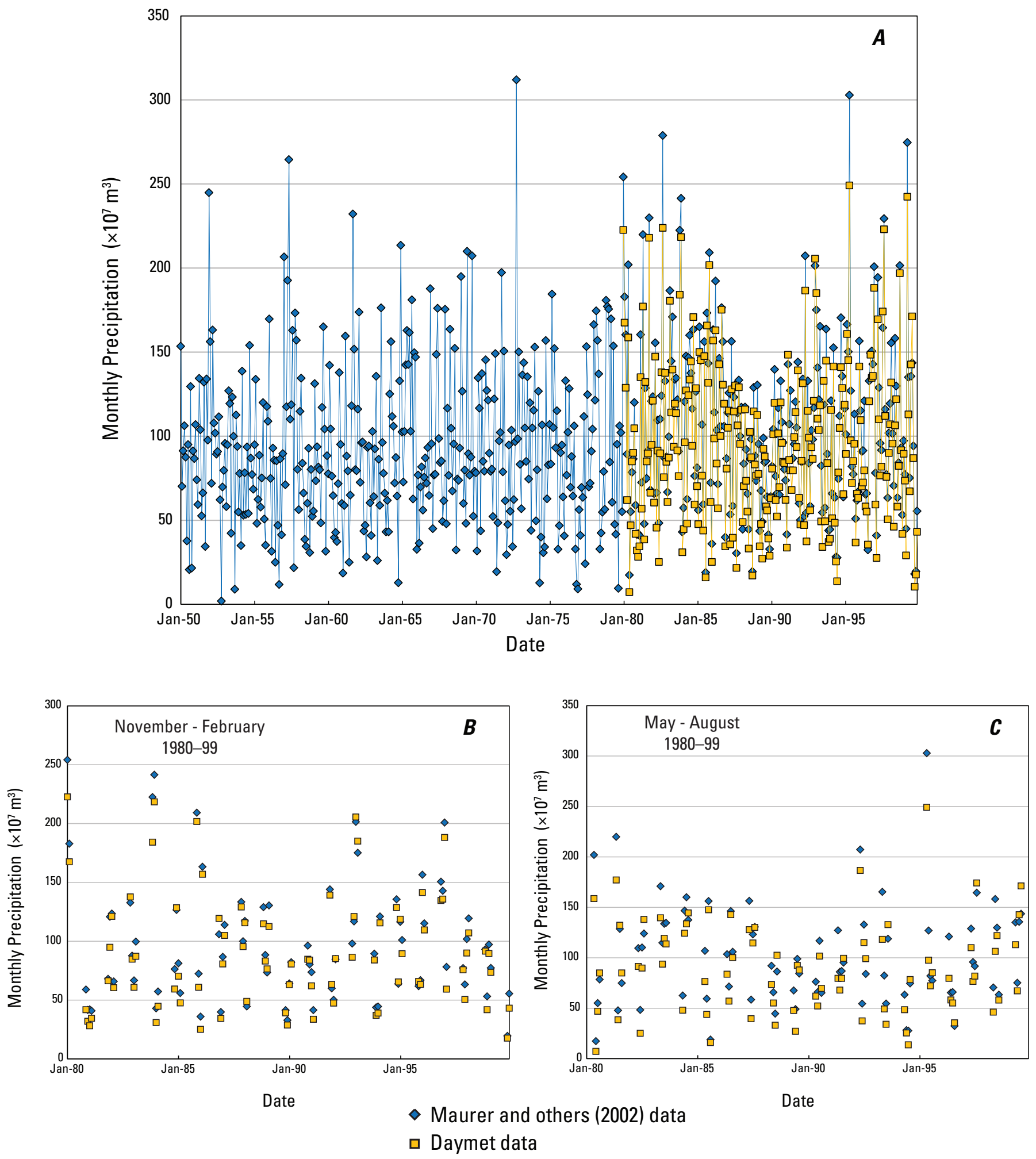

Figure 2. Graphs showing monthly precipitation (in cubic meters, $\mathrm{m}^{3}$ ) time series data from Daymet and Maurer and others (2002), datasets for Upper Colorado River Basin including all data $(A)$, and overlapping time period of 1980-99 ( $B$ and $C$ ). 

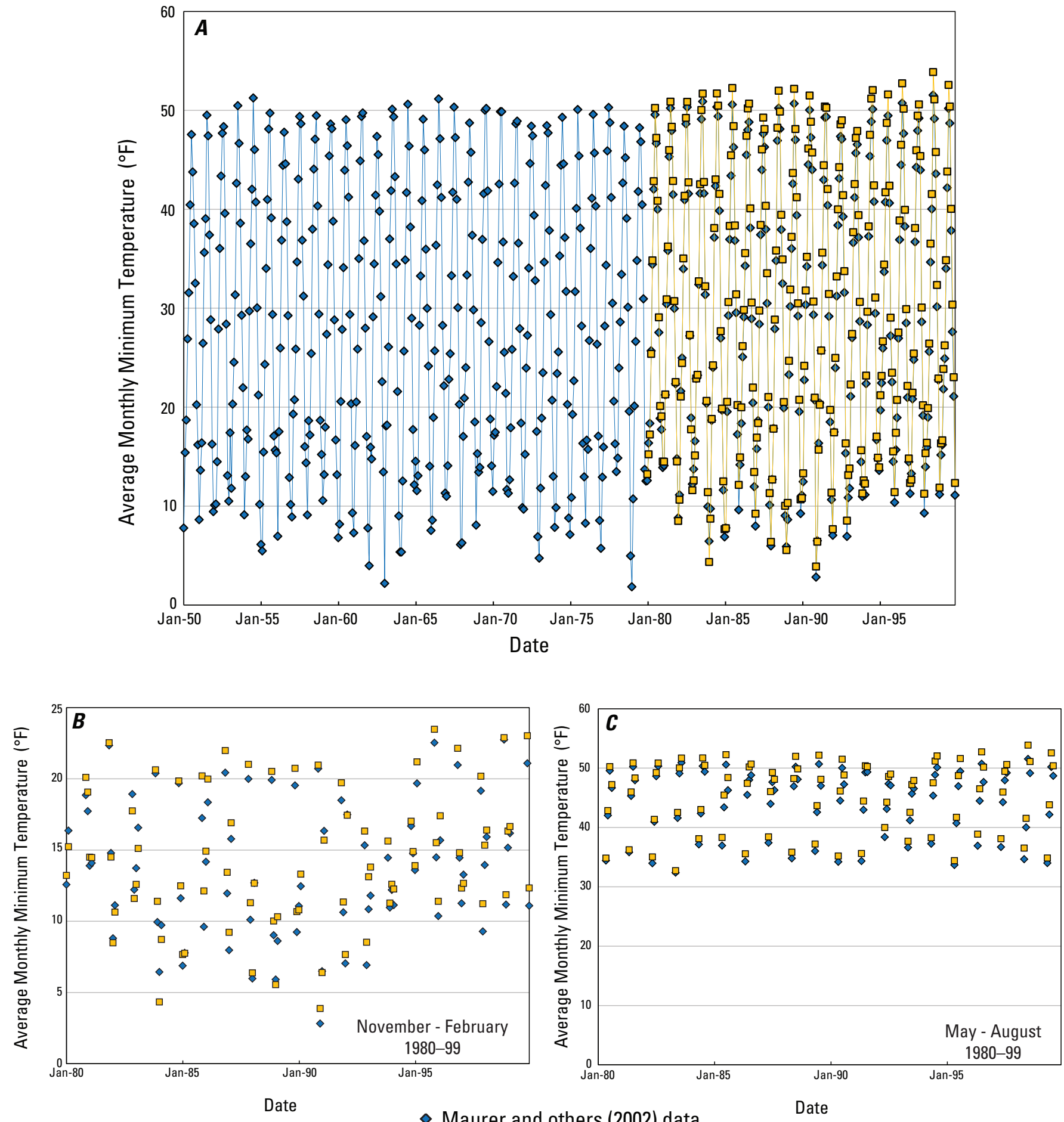

$\checkmark$ Maurer and others (2002) data

- Daymet data

Figure 3. Graphs showing average monthly minimum temperature (in degrees Farenheit, ${ }^{\circ} \mathrm{F}$ ) time series data from Daymet and Maurer and others (2002), datasets for Upper Colorado River Basin including all data $(A)$, and overlapping time period of 1980-99 ( $B$ and $C$ ). 

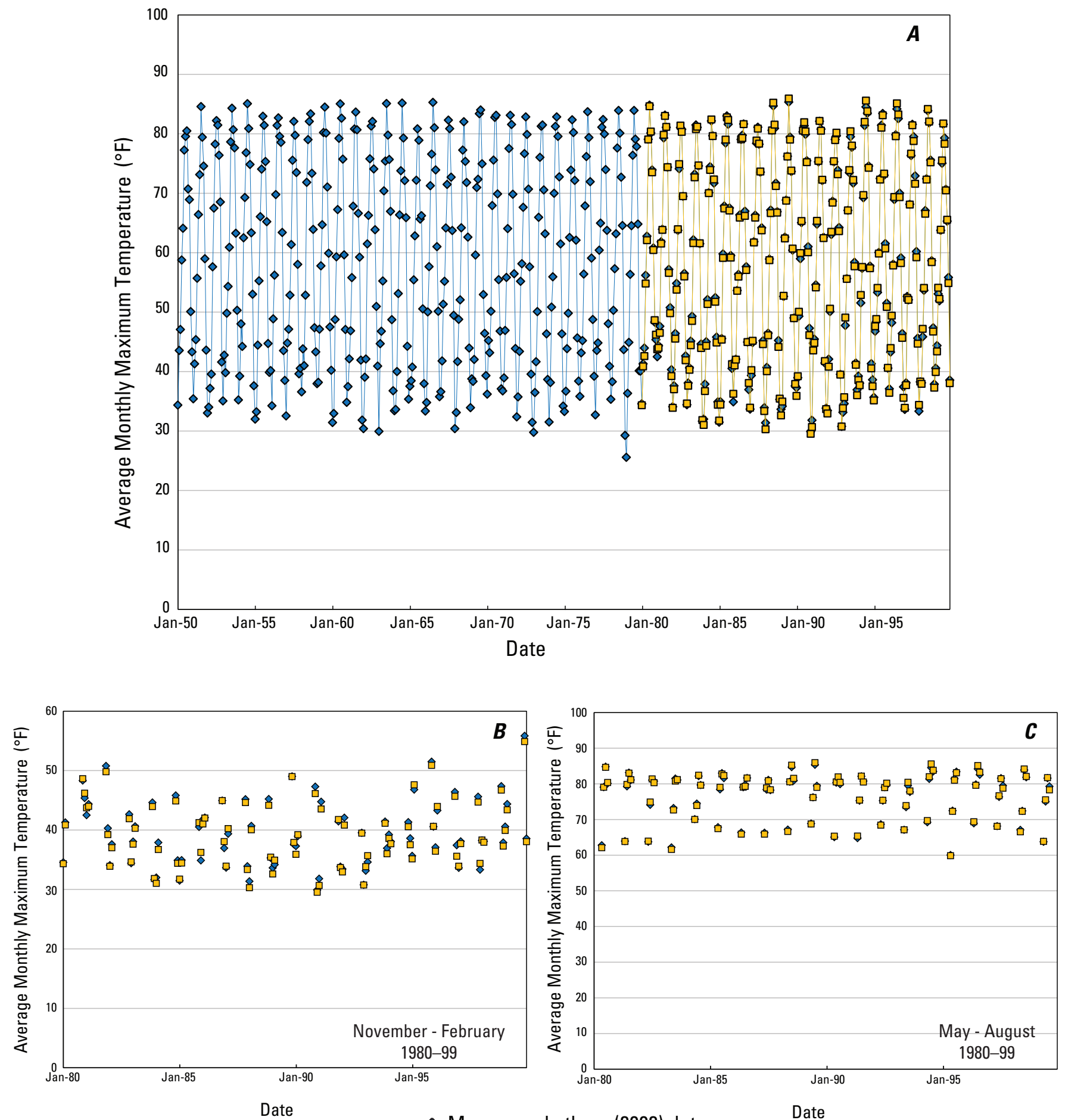

$\diamond$ Maurer and others (2002) data

口 Daymet data

Figure 4. Graphs showing average monthly maximum temperature (in degrees Farenheit, ${ }^{\circ}$ ) ) time series data from Daymet and Maurer and others (2002), datasets for Upper Colorado River Basin including all data ( $A$ ), and overlapping time period of 1980-99 ( $B$ and $C$ ). 


\section{EXPLANATION}

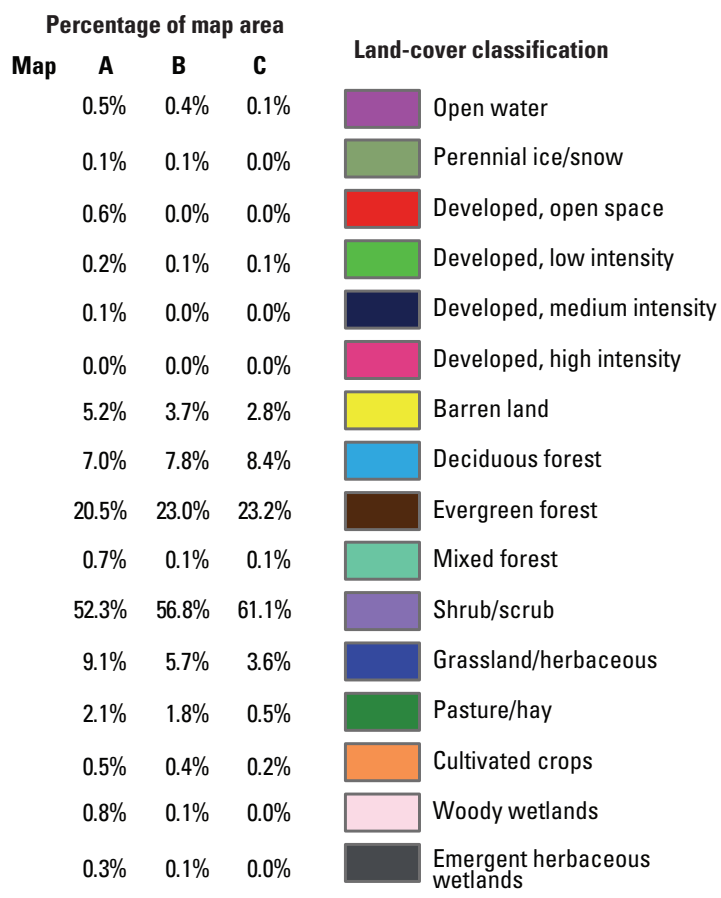

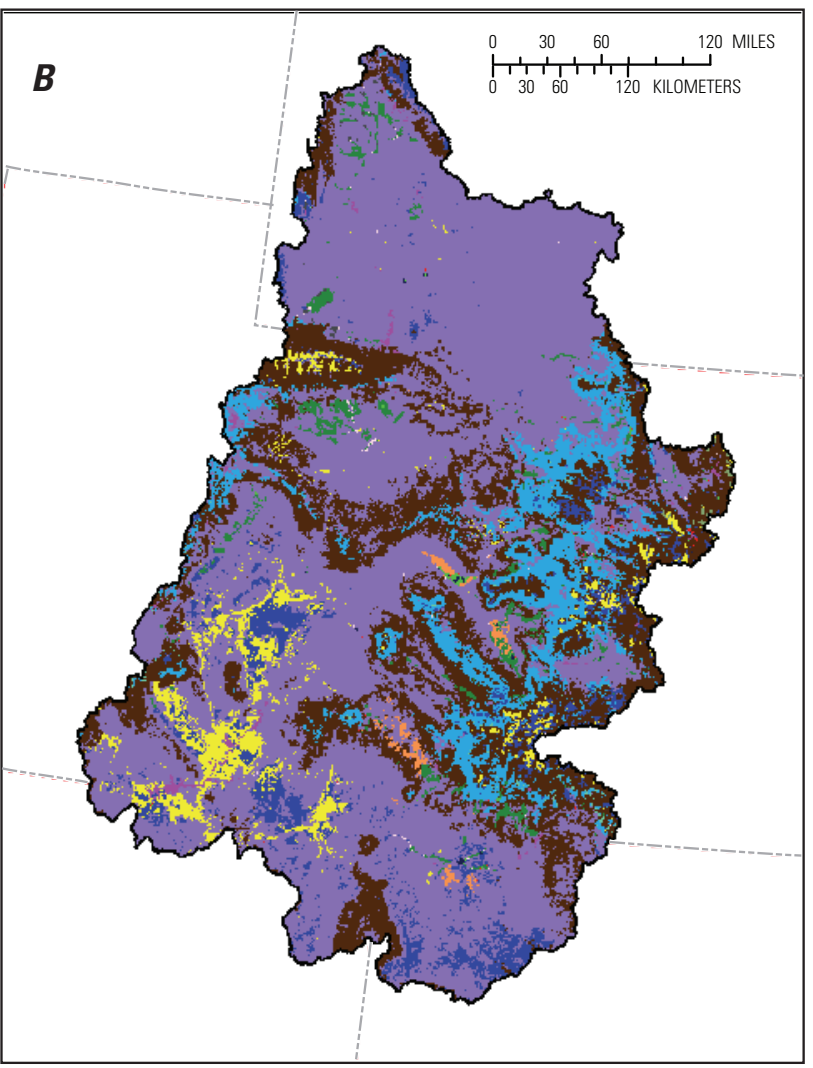

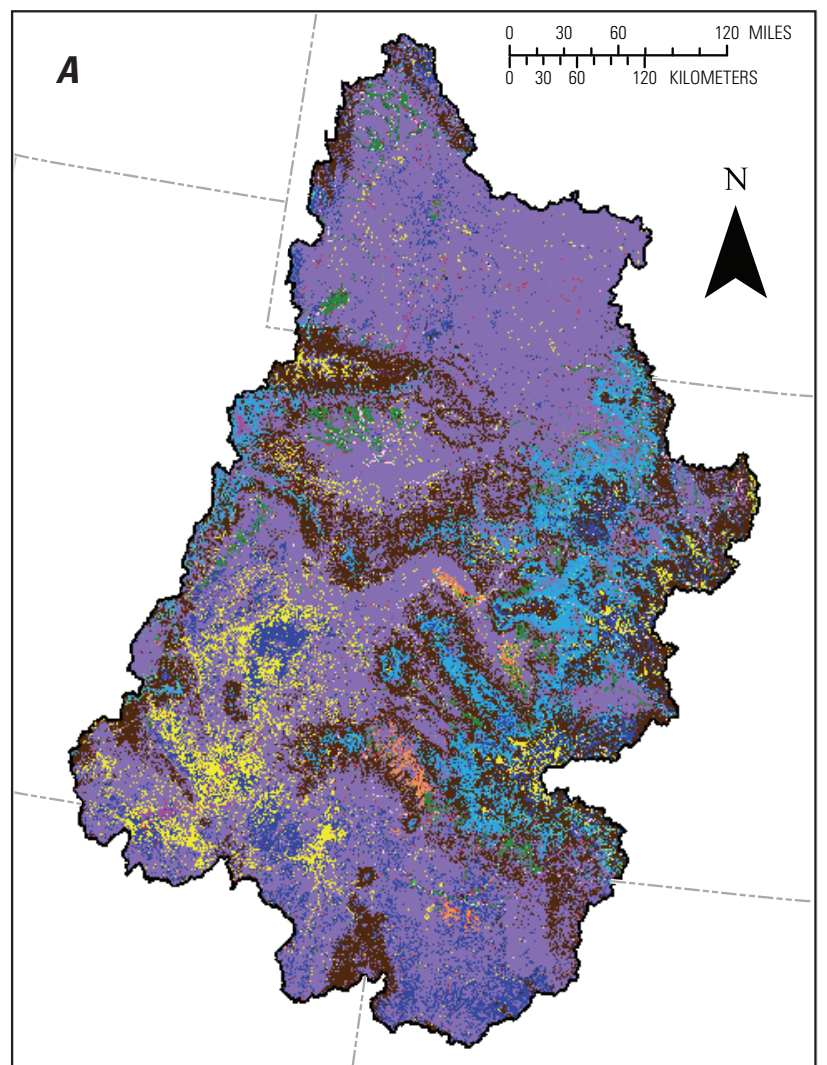

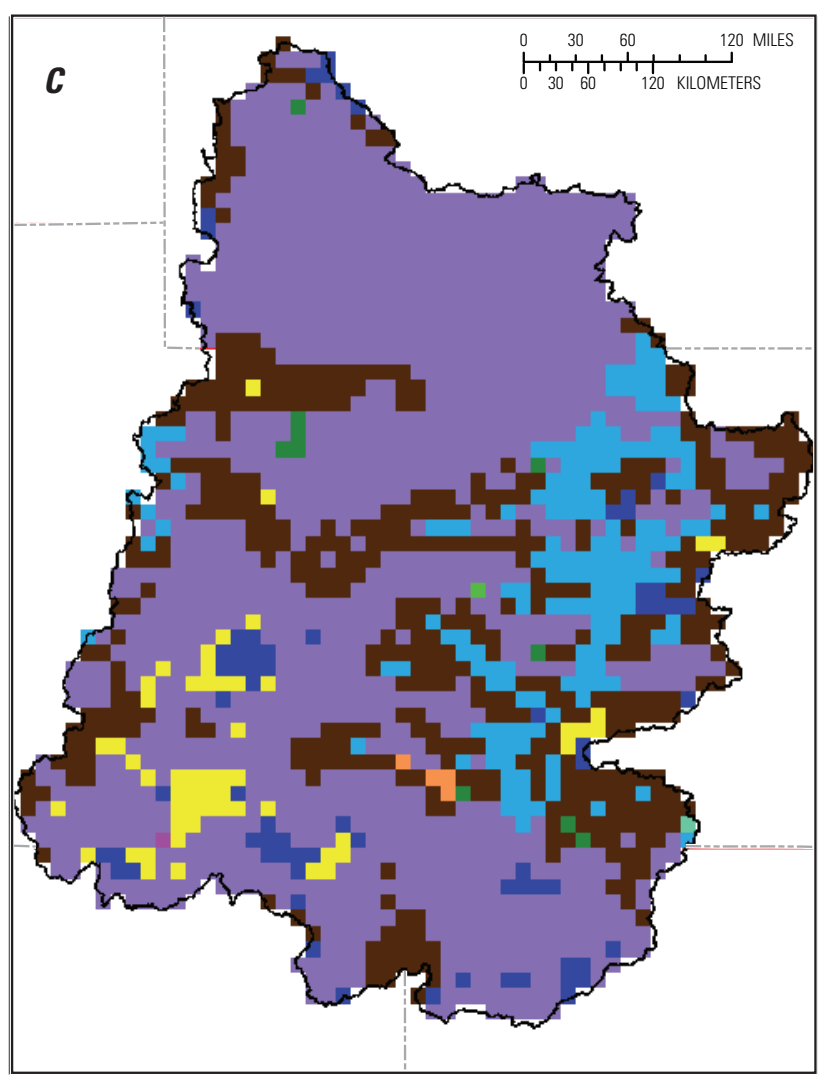

Figure 5. Maps showing National Land Cover Database coverage of the Upper Colorado River Basin study area including the original resolution $(A)$ and resampled resolutions corresponding to Daymet climate dataset $(B)$ and Maurer and other (2002) climate dataset $(C)$. 


\section{EXPLANATION}

D8 flow direction from

central cell

\begin{tabular}{|c|c|c|}
\hline 32 & 64 & 128 \\
\hline 16 & $\begin{array}{c}\text { central } \\
\text { cell }\end{array}$ & 1 \\
\hline 8 & 4 & 2 \\
\hline
\end{tabular}
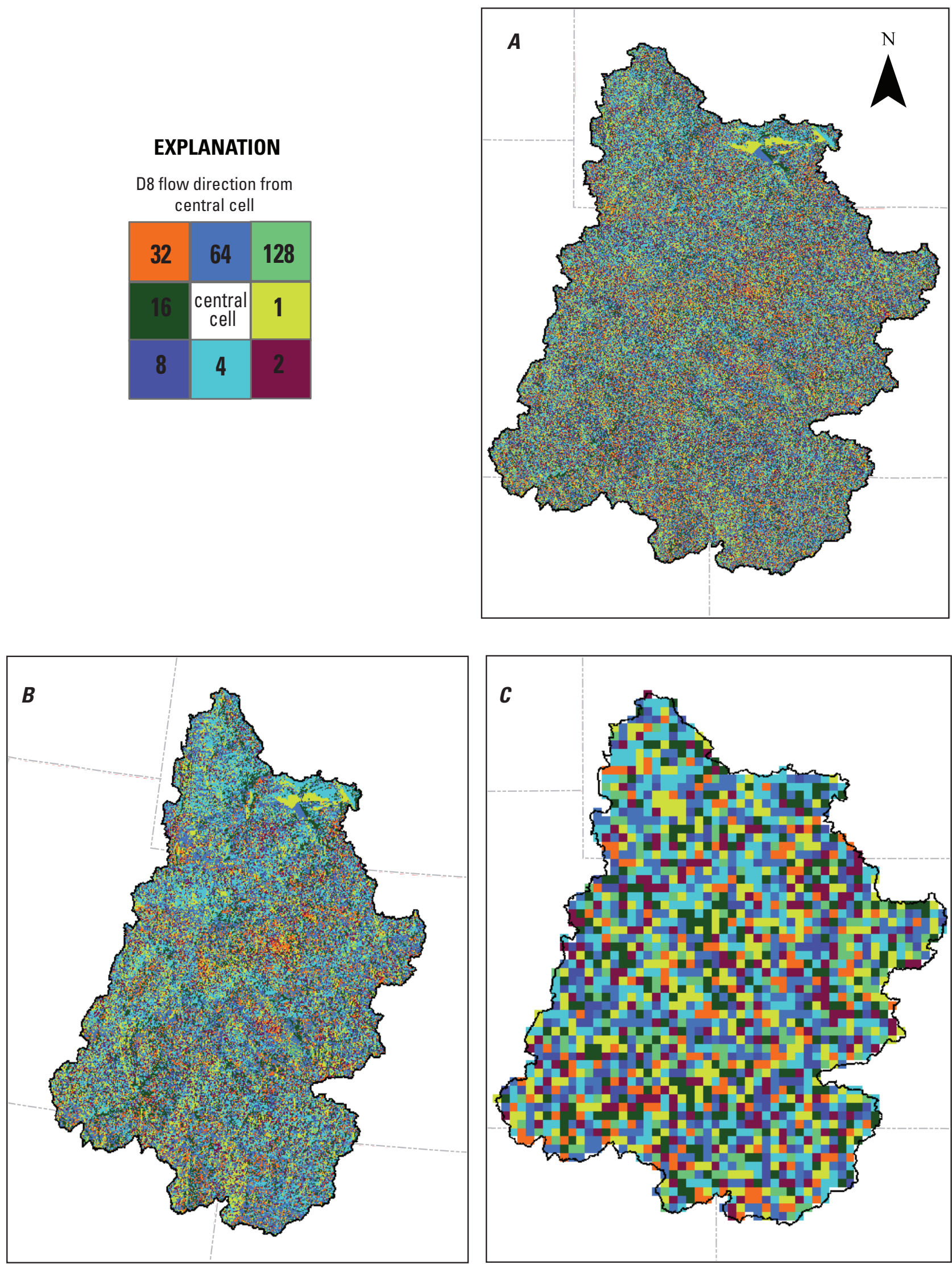

Figure 6. Maps showing overland flow direction from each cell in the Upper Colorado River Basin study area from digital elevation models in original resolution $(A)$, and resampled resolutions corresponding to Daymet climate dataset $(B)$ and Maurer and others (2002) climate dataset $(C)$. 
AWC is multiplied by root-zone depth to define the maximum water capacity of a cell, and any soil-moisture exceeding this amount is converted to recharge. HSG and AWC are discussed together because they are both obtained from the same USDA NRCS geospatial datasets. HSG and AWC information for the UCRB study area were obtained from the NRCS Gridded Soil Survey Geographic (gSSURGO) database, where available, and missing areas were filled in with information from the general NRCS State Soil Geographic (STATSGO2) dataset (fig. 7). gSSURGO data are preferred to STATSGO2 data because they contain information for map units that have a status of provisional, approved, or correlated in the NRCS National Soil Information System database, whereas STATSGO2 information is more general in nature and includes areas where no mapping has occurred (James Bauchert, NRCS, written commun., 10/9/2014).

The gSSURGO and STATSGO2 datasets, covering the five UCRB basin states, were downloaded from the USDA Geospatial Data Gateway (http://datagateway. nrcs.usda.gov/). The gSSURGO dataset is published as 10-m-resolution geodatabase rasters in the Contiguous Albers Equal Area Conic projection. The gSSURGO rasters were combined using the ArcGIS "mosaic to new raster" tool, and associated soil attribute tables were merged and joined to the combined raster. The combined gSSURGO raster was clipped to the UCRB study area using the ArcGIS "extract by mask" tool, and separate HSG and AWC rasters were created using the Reclass tool. STATSGO2 data were downloaded as polygon shapefiles from the NRCS and all states were merged into a single shapefile. Soil tabular data for STATSGO2 polygons are provided in a Microsoft Access database. Reports on Physical Soil Properties (for AWC) and Water Features (for HSG) were run in Microsoft Access and exported to Microsoft Excel. In Excel, Visual Basic for Applications (VBA) scripts were written to compute the depth-weighted average of AWC values, and the majority HSG value, for each map unit. AWC and HSG results were joined to the polygon shapefile and rasters were created for each using the "feature to raster" tool, using the same resolution as the gSSURGO data. A merged raster of gSSURGO and STATSGO2 information was created for each of the AWC and HSG datasets using the CON tool, whereby gSSURGO information was used where available and STATSGO2 information was used where gSSURGO was missing (fig. 7).

The HSG and AWC grids were resampled to obtain the same cell size, cell alignment, and geographic projection as the two climate datasets described previously using the "project raster" tool with the majority and cubic resampling techniques, respectively and the corresponding climate dataset raster to define the output cell size and "snap" raster (figs. 8 and 9). AWC coverage does not vary much by resolution, with a maximum 6-percent difference between the $10-\mathrm{m}$ original and $1 / 8^{\text {th }}$ degree resolutions for 0 to $0.5 \mathrm{in} / \mathrm{ft}$ and 1 to $1.5 \mathrm{in} / \mathrm{ft}$ categories (fig. 8). HSG differences between resolutions are even less varied, with a maximum 1-percent difference between any resolution for all HSGs (fig. 9).

\section{UCRB SWB Table Input Datasets}

Tabular information required for SWB simulations includes runoff curve numbers, maximum daily infiltration rates, and vegetation rooting depths for each combination of hydrologic soil group and land-cover type, plus interception storage values for land-cover types. Runoff curve numbers are an indication of relative runoff potential of an area, with higher numbers indicating higher runoff potential. Curve number information was obtained primarily from the NRCS National Hydrology Handbook (U.S. Department of Agriculture, 2004), with values from Westenbroek and others (2010) used when NRCS curve numbers were unavailable (table 1).

Maximum daily infiltration rates for HSG-land-cover combinations are used by the SWB model to limit the maximum amount of recharge in any cell to what would be considered a reasonable amount. For the UCRB SWB model, a single maximum daily infiltration rate was used for each HSG across all land-cover types: 2 in/day for HSG A, 0.6 in/day for HSG B, $0.24 \mathrm{in} /$ day for HSG C, and $0.12 \mathrm{in} /$ day for HSG D (Westenbroek and others, 2010). Vegetation rooting depths are an important parameter in SWB simulations. The maximum soil-water capacity of a model cell is defined by the product of the available water capacity of the cell multiplied by the root-zone depth of the cell. Groundwater recharge occurs only when soil moisture exceeds the maximum soil-water capacity of a model cell. Root-zone depths for HSG-land-cover combinations (table 2) were obtained from maximum depths reported in Canadell and others (1996) where available, otherwise, values from Westenbroek and others (2010) were used.

Interception storage values are a sink in water-balance equation 1 and represent water that is trapped by vegetation or evaporated from plant surfaces (Westenbroek and others, 2010). Precipitation must exceed interception before any water can reach the soil surface. SWB can utilize separate interception storage values for land-cover types for growing and non-growing (dormant) seasons. For the UCRB SWB model, a value of $0.0835 \mathrm{in}$. (Westenbroek and others, 2010) was used for all land-cover types during the growing season except open water, perennial ice and snow, barren land, and emergent herbaceous wetland land-cover types, which were assigned a value of zero (Westenbroek and others, 2010). All land-cover types were assigned an interception value of zero during the dormant season (Westenbroek and others, 2010).

\section{Sensitivity Analysis Using SWB Table Datasets}

A simple sensitivity analysis was performed on table input values to provide some insight into the importance of particular table parameters on recharge results. The exact uncertainty in any particular HSG-land-cover value for any of the table inputs is unknown. For this sensitivity analysis, curve number, maximum infiltration rates, interception storage values, and root-zone depths were adjusted higher and lower by 25 percent, with a maximum curve number of 100 and minimum values of 0 for all parameters. 


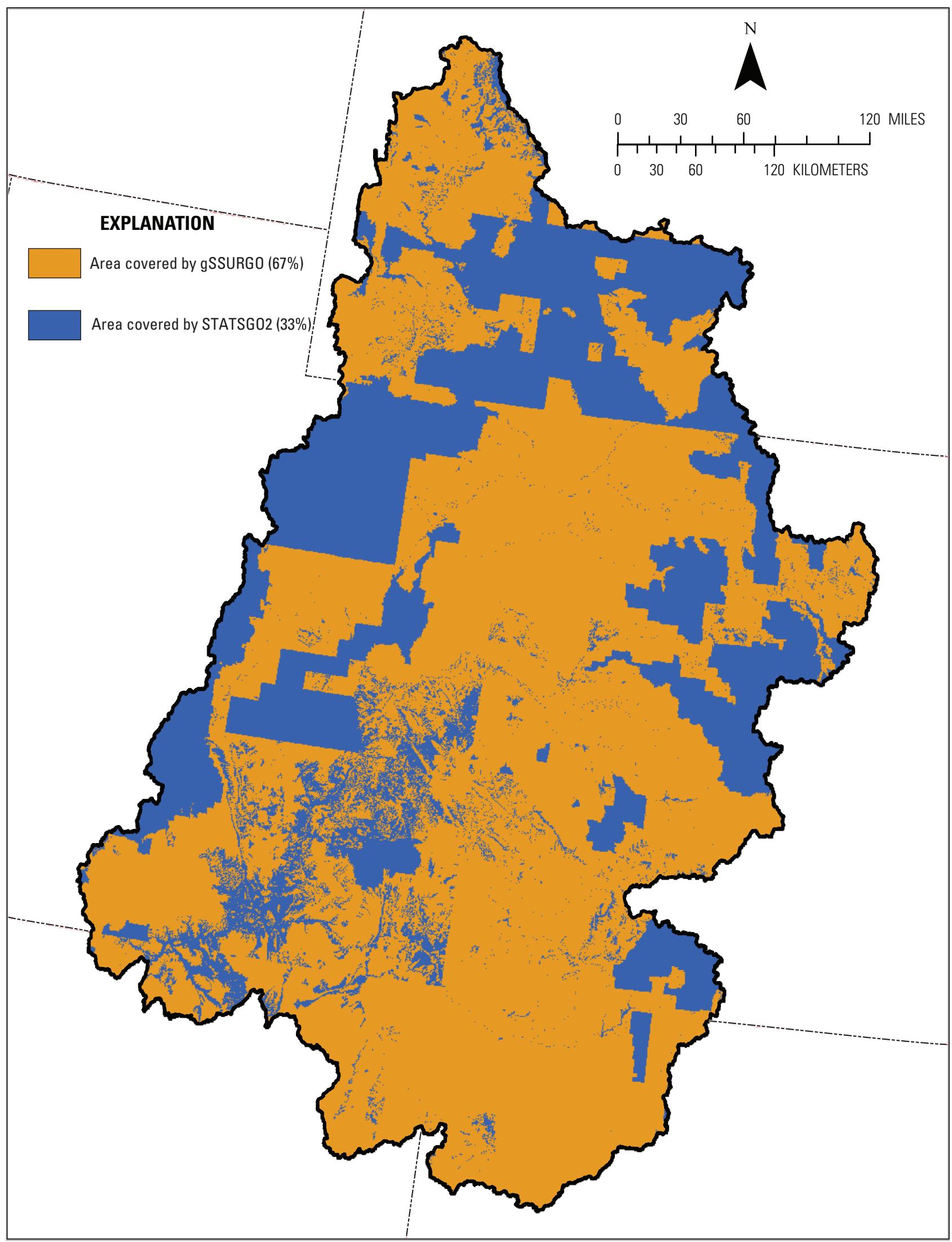

Figure 7. Map showing coverage of the Upper Colorado River Basin study area by gSSURGO and STATSGO2 soils-information datasets. 

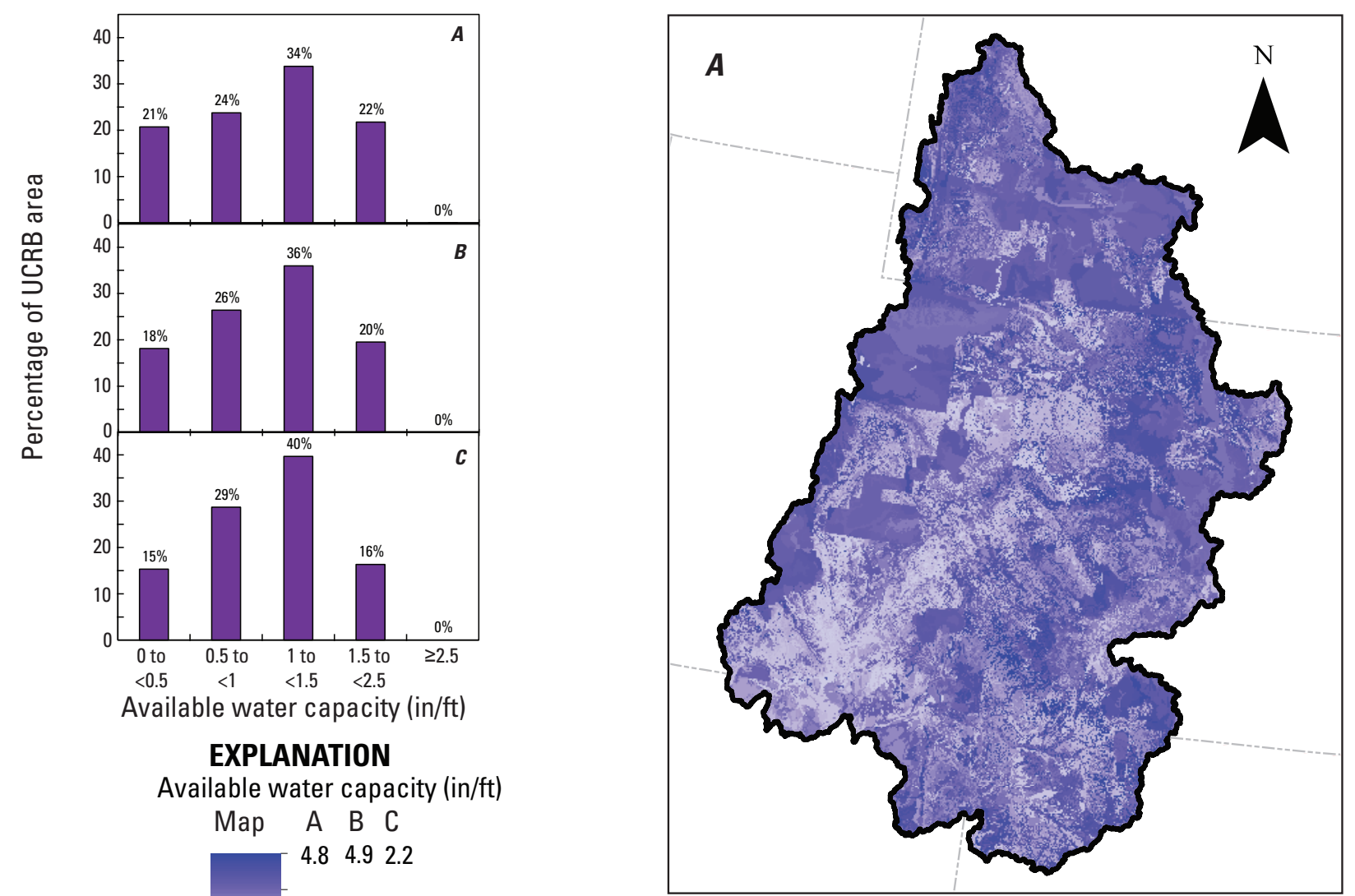

EXPLANATION
Available water capacity (in/ft)

$$
\begin{array}{cccc}
\text { Map } & \text { A } & \text { B } & \text { C } \\
& 4.8 & 4.9 & 2.2
\end{array}
$$
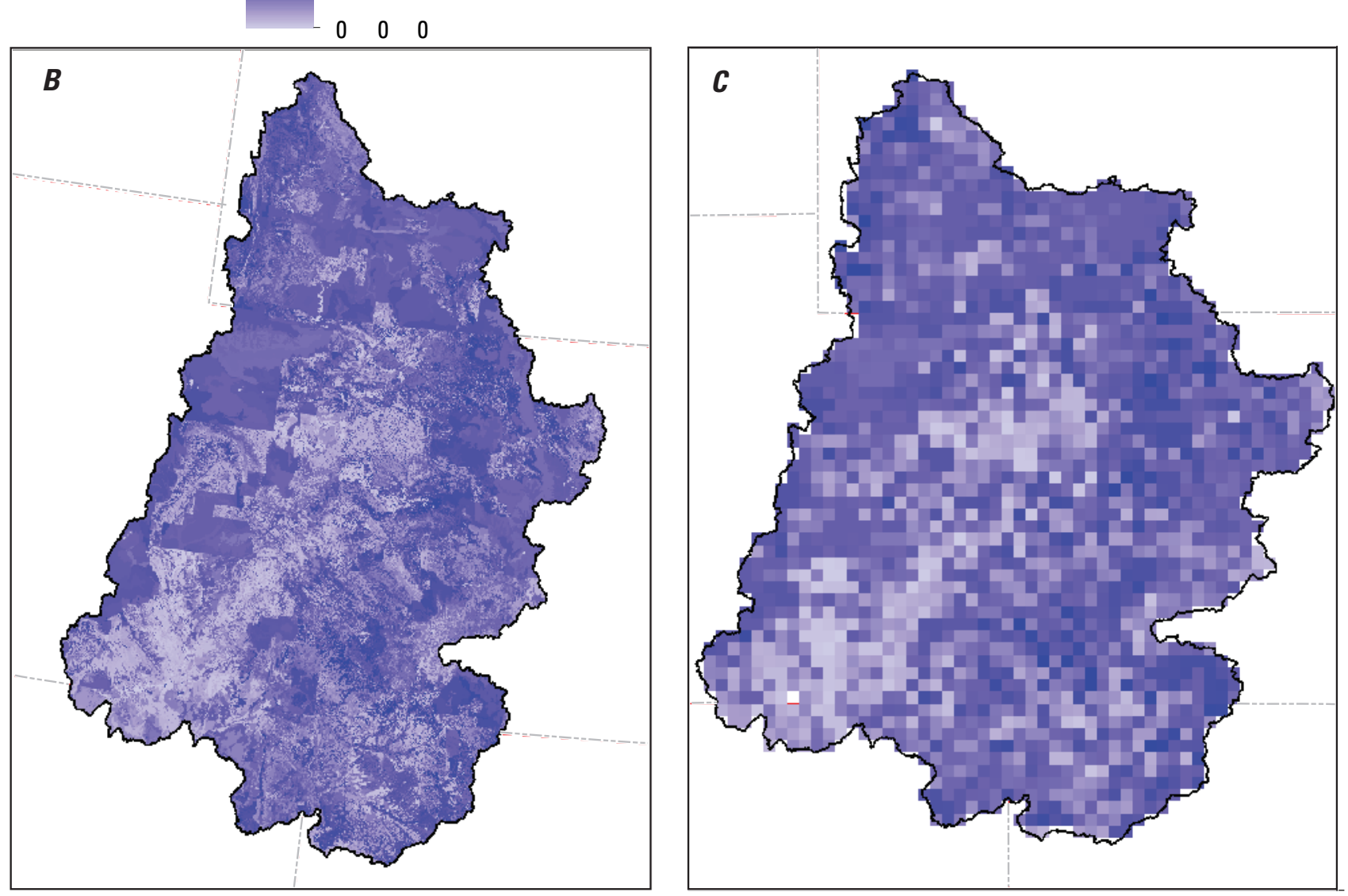

Figure 8. Maps showing percentage of coverage of available water capacity (AWC) for the Upper Colorado River Basin (UCRB) study area including data in original gSSURGO dataset resolution $(A)$, and resampled resolutions corresponding to Daymet climate dataset $(B)$ and Maurer and others (2002) climate dataset $(C)$. 


\section{EXPLANATION}

\begin{tabular}{|c|c|c|c|c|}
\hline \multicolumn{4}{|c|}{ Percentage of map area } & \multirow{2}{*}{$\begin{array}{l}\text { Hydrologic } \\
\text { soil group }\end{array}$} \\
\hline Map & $A$ & B & C & \\
\hline & $6 \%$ & $6 \%$ & $6 \%$ & $A$ \\
\hline & $34 \%$ & $34 \%$ & $35 \%$ & B \\
\hline & $22 \%$ & $23 \%$ & $23 \%$ & C \\
\hline & $37 \%$ & $37 \%$ & $36 \%$ & D \\
\hline
\end{tabular}
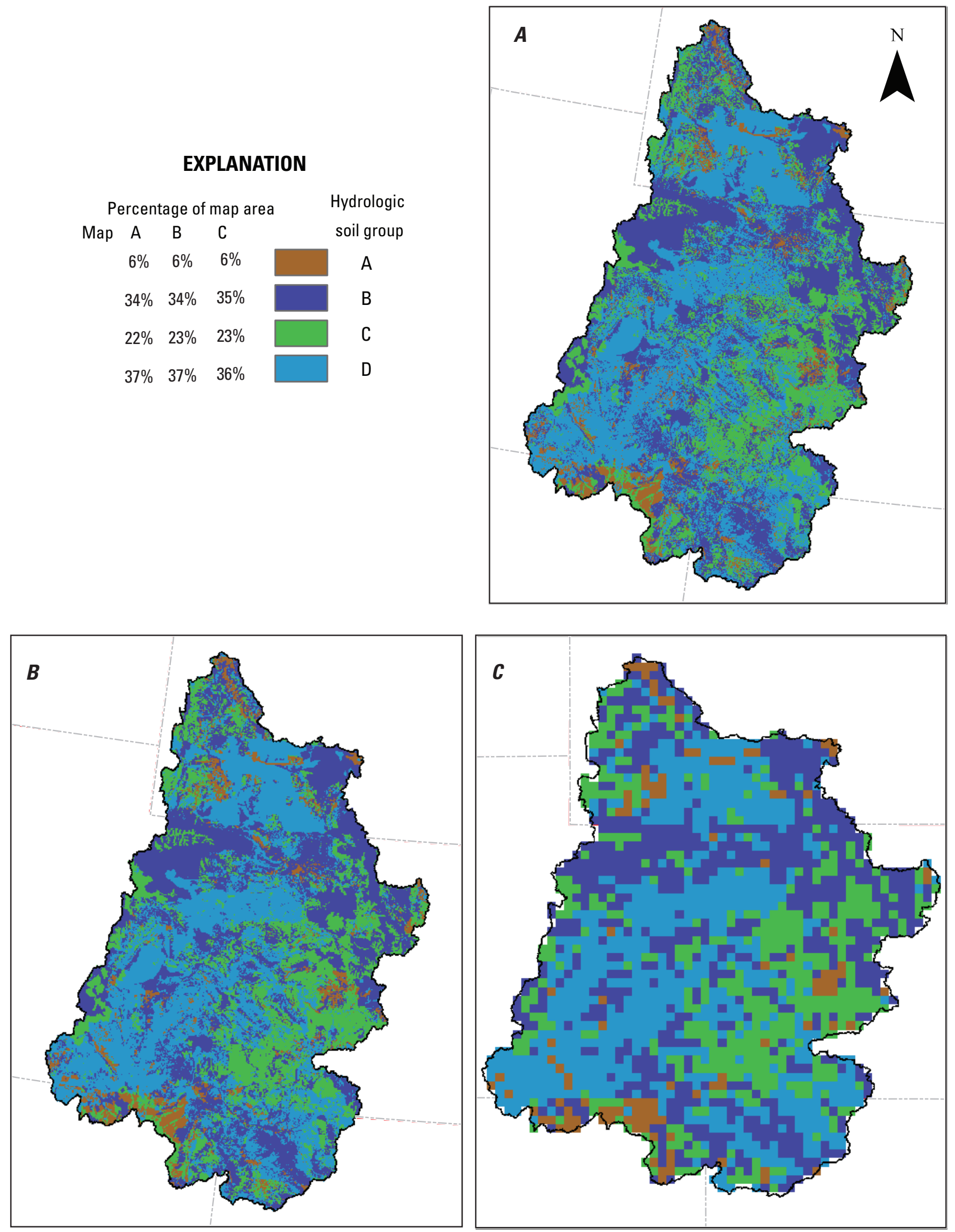

Figure 9. Maps showing Hydrologic Soil Group (HSG) for the Upper Colorado River Basin study area including data in original gSSURGO dataset resolution $(A)$, and resampled resolutions corresponding to Daymet climate dataset $(B)$ and Maurer and others (2002) climate dataset (C). 
Table 1. Soil-water balance model lookup table values and citations for runoff curve numbers.

[HSG, hydrologic soil group; NLCD, National Land Cover Database; UCRB, Upper Colorado River Basin]

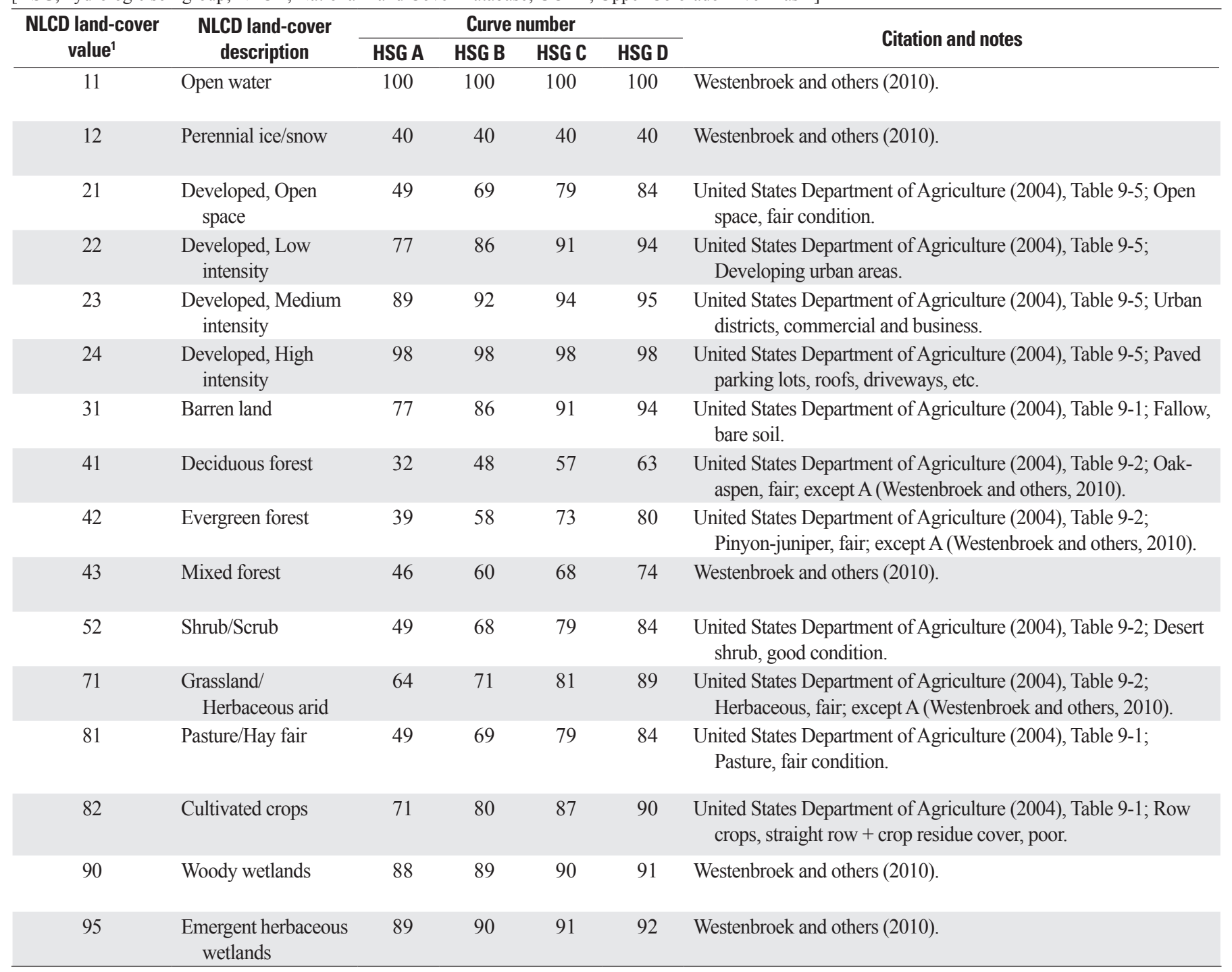

${ }^{1}$ Land-cover values are listed for original NLCD resolution of the UCRB study area. 
Table 2. Soil-water balance model lookup table values and citations for vegetation root-zone depths.

[ft, feet; HSG, hydrologic soil group; NLCD, National Land Cover Database; UCRB, Upper Colorado River Basin]

\begin{tabular}{|c|c|c|c|c|c|c|}
\hline \multirow{2}{*}{$\begin{array}{c}\text { NLCD } \\
\text { land-cover } \\
\text { value }^{1}\end{array}$} & \multirow{2}{*}{$\begin{array}{l}\text { NLCD land-cover } \\
\text { description }\end{array}$} & \multicolumn{4}{|c|}{ Depth of root zone (ft) } & \multirow[b]{2}{*}{ Citation and notes } \\
\hline & & HSG A & HSG B & HSG C & HSG D & \\
\hline 11 & Open water & 0 & 0 & 0 & 0 & Westenbroek and others (2010). \\
\hline 12 & Perennial ice/snow & 0 & 0 & 0 & 0 & Westenbroek and others (2010). \\
\hline 21 & Developed, Open space & 8.53 & 8.53 & 8.53 & 8.53 & $\begin{array}{l}\text { Canadell and others (1996); average maximum of } \\
\text { temperate grassland biome. }\end{array}$ \\
\hline 22 & $\begin{array}{l}\text { Developed, Low } \\
\text { intensity }\end{array}$ & 8.53 & 8.53 & 8.53 & 8.53 & $\begin{array}{l}\text { Canadell and others (1996); average maximum of } \\
\text { temperate grassland biome. }\end{array}$ \\
\hline 23 & $\begin{array}{l}\text { Developed, Medium } \\
\text { intensity }\end{array}$ & 8.53 & 8.53 & 8.53 & 8.53 & $\begin{array}{l}\text { Canadell and others (1996); average maximum of } \\
\text { temperate grassland biome. }\end{array}$ \\
\hline 24 & $\begin{array}{l}\text { Developed, High } \\
\text { intensity }\end{array}$ & 8.53 & 8.53 & 8.53 & 8.53 & $\begin{array}{l}\text { Canadell and others (1996); average maximum of } \\
\text { temperate grassland biome. }\end{array}$ \\
\hline 42 & Evergreen forest & 12.8 & 12.8 & 12.8 & 12.8 & $\begin{array}{l}\text { Canadell and others (1996); average maximum of } \\
\text { temperate coniferous forest biome. }\end{array}$ \\
\hline 43 & Mixed forest & 11.15 & 11.15 & 11.15 & 11.15 & $\begin{array}{l}\text { Canadell and others (1996); average temperate } \\
\text { deciduous and coniferous forest biomes. }\end{array}$ \\
\hline 52 & Shrub/Scrub & 3.5 & 3.5 & 3.5 & 3.5 & Westenbroek and others (2010). \\
\hline 71 & $\begin{array}{l}\text { Grassland/Herbaceous } \\
\text { arid }\end{array}$ & 8.53 & 8.53 & 8.53 & 8.53 & $\begin{array}{l}\text { Canadell and others (1996); average maximum of } \\
\text { temperate grassland biome. }\end{array}$ \\
\hline 81 & Pasture/Hay fair & 8.53 & 8.53 & 8.53 & 8.53 & $\begin{array}{l}\text { Canadell and others (1996); average maximum of } \\
\text { temperate grassland biome. }\end{array}$ \\
\hline
\end{tabular}

${ }^{1}$ Land-cover values are listed for original NLCD resolution of the UCRB study area. 
Owing to the potential for a larger range of values, root-zone depths were also adjusted higher and lower by 75 percent. A base case SWB simulation was run with the table values described previously using the Daymet climate data and Daymet-resolution gridded input datasets described in the previous section. Table values for a single parameter (for example, curve number) were adjusted to their high range and the model was run again. Table values for the same parameter were adjusted to their low range and the model was run again. This method was repeated for all four table parameters separately. The combined effect of the range of all table values was not investigated. Results of the sensitivity analysis indicate that changes in root-zone depth over the ranges investigated have a relatively large effect on simulated recharge results (table 3 ). Increasing curve numbers by 25 percent, up to a maximum of 100 , results in a 30 -percent increase in simulated recharge over the base case values, whereas a reduction in curve numbers by the same percentage has almost no impact on simulated recharge (table 3).

Table 3. Sensitivity of Upper Colorado River Basin soil-water balance model simulated recharge results for different lookuptable values.

[ft/yr, feet/year; na, not applicable]

\begin{tabular}{lcc}
\hline $\begin{array}{c}\text { “Lookup table parameter } \\
\text { and change" }\end{array}$ & $\begin{array}{c}\text { 1980-1999 average } \\
\text { annual recharge } \\
\text { (acre-ft/yr) }\end{array}$ & $\begin{array}{c}\text { Percentage } \\
\text { change from } \\
\text { base case }\end{array}$ \\
\hline Base case values & $7,260,808$ & na \\
+25\% curve numbers & $9,466,198$ & 130 \\
-25\% curve numbers & $7,247,618$ & 100 \\
+25\% max infiltration rates & $7,902,314$ & 109 \\
-25\% max infiltration rates & $6,300,007$ & 87 \\
+25\% interception storage & $7,166,594$ & 99 \\
-25\% interception storage & $7,409,432$ & 102 \\
+25\% root-zone depths & $6,201,574$ & 85 \\
-25\% root-zone depths & $8,783,284$ & 121 \\
$+75 \%$ root-zone depths & $4,869,730$ & 67 \\
-75\% root-zone depths & $15,334,917$ & 211 \\
\hline
\end{tabular}

\section{Summary}

The source and manipulation of five spatially distributed datasets used in UCRB SWB recharge simulations were discussed, including daily climate data (precipitation, maximum and minimum air temperature), land cover, overland flow direction, hydrologic soil group, and available soil-water capacity. Citations for lookup table information required for SWB simulations were also documented. Lookup table parameters include runoff curve numbers, maximum daily infiltration rates, and vegetation rooting depths for each combination of hydrologic soil group and land-cover type, plus interception storage values for only land-cover types.

\section{References Cited}

Allen, R.G., Pereira, L.S., Raes, D., and Smith, M., 1998 (with errata 2006), Crop evapotranspiration - Guidelines for computing crop water requirements: FAO Irrigation and Drainage Paper No. 56, Food and Agricultural Organization of the United Nations, Rome, Italy, 333 p., available at http://www.fao.org/docrep/x0490e/ x0490e00.htm\#Contents.

Anderson, D.L., 2004, History of the development of the Colorado River and "The law of the River," in Rogers, J.R., Brown, G.O., and Garbrecht, J.D., Water Resources and Environmental History, p. 75-81, doi:10.1061/40738(140)11.

Bureau of Reclamation, 2011, Quality of water, Colorado River Basin, progress report no. 23: Bureau of Reclamation, 76 p., http:/www.usbr.gov/uc/progact/salinity/pdfs/PR23final.pdf.

Canadell, J., Jackson, R.B., Ehleriger, J.R., Mooney, H.A., Sala, O.E., and Schulze, E.D., 1996, Maximum rooting depth of vegetation types at the global scale: Oecologia v. 108, no. 4, p. 583-595.

Castle, S.L., Thomas, B.F., Reager, J.T., Rodell, M., Swenson, S.C., and Famiglietti, J.S., 2014, Groundwater depletion during drought threatens future water security of the Colorado River Basin: Geophysical Research Letters, v. 41, no. 16, p. 5904-5911, doi:10.1002/2014GL061055.

Colorado River Basin Salinity Control Forum, 2011, Water quality standards for salinity, Colorado River system, 2011 review: Bountiful, Utah, Colorado River Basin Salinity Control Forum, 99 p., http://www.coloradoriversalinity.org/docs/2011\%20 REVIEW-October.pdf.

Colorado River Basin Salinity Control Forum, 2013, Colorado River Basin salinity control program, briefing document: Bountiful, Utah, Colorado River Basin Salinity Control Forum, 4 p., http:// www.coloradoriversalinity.org/docs/CRBSCP $\% 20$ Briefing $\% 20$ Document\%202015-05-01-new\%20map.pdf.

Freethey, G.W., and Cordy, G.E., 1991, Geohydrology of Mesozoic rocks in the upper Colorado River basin in Arizona, Colorado, New Mexico, Utah, and Wyoming, excluding the San Juan Basin: U.S. Geological Survey, Professional Paper 1411-C, 118 p., 6 plates, http://pubs.er.usgs.gov/publication/pp1411C.

Fry, J., Xian, G., Jin, S., Dewitz, J., Homer, C., Yang, L., Barnes, C., Herold, N., and Wickham, J., 2011, Completion of the 2006 National Land Cover Database for the conterminous United States: Photogrammetric Engineering \& Remote Sensing, v. 77, no. 9, p. 858-864, available at http://www.mrlc.gov/ downloadfile2.php?file=September2011PERS.pdf.

Geldon, A.L., 2003a, Geology of Paleozoic Rocks in the Upper Colorado River Basin in Arizona, Colorado, New Mexico, Utah, and Wyoming, Excluding the San Juan Basin: U.S. Geological Survey, Professional Paper 1411-A, 112 p., 18 plates, http://pubs. er.usgs.gov/publication/pp1411A. 
Geldon, A.L, 2003b, Hydrologic properties and ground-water flow systems of the Paleozoic rocks in the upper Colorado River basin in Arizona, Colorado, New Mexico, Utah, and Wyoming, excluding the San Juan Basin: U.S. Geological Survey Professional Paper 1411-B, 153 p., 13 plates, http://pubs.er.usgs. gov/publication/pp1411B.

Hargreaves, G.H., and Samani, Z.A., 1985, Reference crop evapotranspiration from temperature: Applied Engineering in Agriculture, v. 1, no. 2, p. 96-99.

Homer, C.G., Dewitz, J.A., Yang, L., Jin, S., Danielson, P., Xian, G., Coulston, J., Herold, N.D., Wickham, J.D., and Megown, K., 2015, Completion of the 2011 National Land Cover Database for the conterminous United States-Representing a decade of land cover change information: Photogrammetric Engineering and Remote Sensing, v. 81, no. 5, p. 345-354.

Liebermann, T.D., Mueller, D.K., Kircher, J.E., and Choquette, A.F., 1989, Characteristics and trends of streamflow and dissolved solids in the Upper Colorado River Basin, Arizona, Colorado, New Mexico, Utah, and Wyoming: U.S. Geological Survey Water-Supply Paper 2358, 64 p., map plate, available at http:// pubs.usgs.gov/wsp/2358/report.pdf.

Maurer, E.P., Wood, A.W., Adam, J.C., Lettenmaier, D.P., and Nijssen, B., 2002, A long-term hydrologically based dataset of land surface fluxes and states for the conterminous United States: Journal of Climate, v. 15, no. 22, p. 3237-3251, available at http:// dx.doi.org/10.1175/1520-0442(2002)015<3237:ALTHBD>2.0 .CO;2.

Miller, M.P., Susong, D.D., Shope, C.L., Heilweil, V.M., and Stolp, B.J., 2014, Continuous estimation of baseflow in snowmelt-dominated streams and rivers in the Upper Colorado River Basin: A chemical hydrograph separation approach: Water Resources Research, v. 50, no. 8, p. 6986-6999, doi:10.1002/2013WR014939.
O'Callaghan, J.F. and Mark, D.M., 1984, The extraction of drainage networks from digital elevation data: Computer Vision, Graphics, and Image Processing, v. 28, no. 3, p. 323-344, doi:10.1016/S0734-189X(84)80011-0.

PRISM Climate Group, 2012, Digital climate data: PRISM Climate Group, Oregon State University, accessed January 2012 at http://www.prism.oregonstate.edu/.

Robson, S.G., and Banta, E.R., 1995, Ground Water Atlas of the United States, Segment 2, Arizona, Colorado, New Mexico, Utah: U.S. Geological Survey Hydrologic Investigations Atlas 730-C, 32 p., http://pubs.usgs.gov/ha/ ha730/gwa.html.

U.S. Department of Agriculture, 1998, Soil Quality Resource Concerns, Available Water Capacity: Soil Quality Information Sheet, 2 p., available at http://www.nrcs.usda. gov/Internet/FSE_DOCUMENTS/nrcs142p2_051279.pdf.

U.S. Department of Agriculture, 2004, Chapter 9, Hydrologic Soil-Cover Complexes in Part 630 Hydrology, National Engineering Handbook, 210-VI-NEH, July 2004, 20 p., available at http://www.wcc.nrcs.usda.gov/ftpref/wntsc/ H\&H/NEHhydrology/ch9.pdf.

U.S. Department of Agriculture, 2009, Chapter 7, Hydrologic Soil Groups in Part 630 Hydrology, National Engineering Handbook, 210-VI-NEH, January 2009, 13 p., available at http:/www.wcc.nrcs.usda.gov/ftpref/wntsc/H\&H/ NEHhydrology/ch7.pdf.

Westenbroek, S.M., Kelson, V.A., Hunt, R.J., and Bradbury, K.R., 2010, SWB-A modified Thornthwaite-Mather SoilWater Balance code for estimating groundwater recharge: U.S. Geological Survey Techniques and Methods 6-A31, 60 p., http://pubs.usgs.gov/tm/tm6-a31/.
Produced in Menlo Park Publishing Science Center, California

Manuscript approved on August 21, 2015

Edited by Sarah Nagorsen

Layout by Cory D. Hurd 


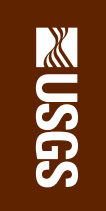

